\title{
Demyelinating Disorder of Central Nervous System
}

National Cancer Institute

\section{Source}

National Cancer Institute. Demyelinating Disorder of Central Nervous System. NCI

Thesaurus. Code C34526.

Any condition in which there is degeneration of the myelin sheath that covers the nerves

of the central nervous system. 